Article

\title{
Ozone Amplifies Water Loss from Mature Trees in the Short Term But Decreases It in the Long Term
}

\author{
Elena Paoletti ${ }^{1} * \mathbb{B}$, Nancy E. Grulke ${ }^{2}$ and Rainer Matyssek ${ }^{3}$ \\ 1 IRET-CNR, Via Madonna del Piano 10, Florence, I-50019 Sesto Fiorentino, Italy \\ 2 USDA WWETAC 3160 NE Third St, PO Box 4903160 NE 3rd Street, Prineville, OR 97754, USA; \\ nancy.grulke@usda.gov \\ 3 Ecophysiology of Plants, WZW, Technical University of Munich, 85354 Freising, Germany; \\ matyssek@wzw.tum.de \\ * Correspondence: elena.paoletti@cnr.it; Tel.: +39-055-522-5591
}

Received: 26 November 2019; Accepted: 27 December 2019; Published: 31 December 2019

check for updates

\begin{abstract}
We measured whole-tree transpiration of mature Fagus sylvatica and Picea abies trees exposed to ambient and twice-ambient $\mathrm{O}_{3}$ regimes ( $1 \mathrm{xO}_{3}$ and $2 \mathrm{xO}_{3}$ free-air fumigation). After eight years, mean daily total transpiration did not vary with the $\mathrm{O}_{3}$ regime over the 31 days of our study, even though individual daily values increased with increasing daily $\mathrm{O}_{3}$ peaks in both species. Although the environmental parameters were similar at $1 \mathrm{xO}_{3}$ and $2 \mathrm{xO}_{3}$, the main factors affecting daily transpiration were vapour pressure deficit in $2 \mathrm{xO}_{3}$ spruce and $\mathrm{O}_{3}$ peaks in beech. For a mechanistic explanation, we measured $\mathrm{O}_{3}$-induced sluggish stomatal responses to variable light (sunflecks) by means of leaf-level gas exchange measurements only in the species where $\mathrm{O}_{3}$ was a significant factor for transpiration, i.e., beech. Stomata were always slower in closing than in opening. The $2 \mathrm{xO}_{3}$ stomata were slower in opening and mostly in closing than $1 \mathrm{xO}_{3}$ stomata, so that $\mathrm{O}_{3}$ uptake and water loss were amplified before a steady state was reached. Such delay in the stomatal reaction suggests caution when assessing stomatal conductance under $\mathrm{O}_{3}$ pollution, because recording gas exchange at the time photosynthesis reached an equilibrium resulted in a significant overestimation of stomatal conductance when stomata were closing ( $\mathrm{ab} .90 \%$ at $1 \mathrm{xO}_{3}$ and $250 \%$ at $\left.2 \mathrm{xO}_{3}\right)$. Sun and shade leaves showed similar sluggish responses, thus suggesting that sluggishness may occur within the entire crown. The fact that total transpiration was similar at $1 \mathrm{xO}_{3}$ and $2 \mathrm{xO}_{3}$, however, suggests that the higher water loss due to stomatal sluggishness was offset by lower steady-state stomatal conductance at $2 \mathrm{xO}_{3}$. In conclusion, $\mathrm{O}_{3}$ exposure amplified short-term water loss from mature beech trees by slowing stomatal dynamics, while decreased long-term water loss because of lower steady-state stomatal conductance. Over the short term of this experiment, the two responses offset each other and no effect on total transpiration was observed.
\end{abstract}

Keywords: sunflecks; Kranzberg; stomatal sluggishness; transpiration; tropospheric ozone; water cycle

\section{Introduction}

Forests cover $30 \%$ of the world's land surface, generate half of the global net primary productivity, and play a significant role in regulating water supply [1]. Carbon assimilation and water use efficiency can be impaired by ground-level ozone $\left(\mathrm{O}_{3}\right)$, an air pollutant of strong concern for forests because of its phytotoxicity and widespread distribution [2-4]. Ozone effects on forest ecosystems include changes in carbon fixation and allocation, shifts in nutrient supply, biodiversity changes, and higher susceptibility to natural disturbances, i.e., insects, disease, fires, wind storms and drought [5-8]. Such changes have important implications for forest responses to climate change. Scalar and conceptual uncertainties limit 
our understanding of the basic physiological mechanisms that underly responses of forests to $\mathrm{O}_{3}[9,10]$. The scalar uncertainties are due to the transfer of results from seedlings in controlled environments to mature forests in the field [11], while the conceptual uncertainties are due to contrasting results about tree water-use responses to ambient $\mathrm{O}_{3}$ (e.g., [12]). A critical issue is thus to define stomatal responses to $\mathrm{O}_{3}$ exposure in mature trees [13].

Stomatal responses to air pollutants are complex, depending on plant species, leaf and tree age, level and length of exposure, and vary in conjunction with other environmental stressors [14,15]. There is a general consensus that stomatal closure is a response to the $\mathrm{O}_{3}$-induced damage to the photosynthetic machinery [5]. In parallel, however, stomatal control of transpiration may be reduced following $\mathrm{O}_{3}$ exposure, leading to wider or narrower stomatal apertures and uncoupling of stomatal conductance and photosynthesis (with effects on instantaneous water-use efficiency, WUEi; [16-21] and allowing for $\mathrm{O}_{3}$ influx at night [19,22-24]. The mechanism explaining delayed and/or slowed closing responses of stomata to fluctuating environmental stimula under $\mathrm{O}_{3}$ stress is termed stomatal sluggishness, defined as a longer time to respond to the 'close' signal and a slower rate of closing $[13,15]$. Paoletti [25] found that the dynamics of stomatal responses to light and water deficit slowed following controlled $\mathrm{O}_{3}$ exposure of Arbutus unedo seedlings. Sluggish stomatal responses are usually observed when $\mathrm{O}_{3}$ exposure is combined with water stress [17,25-27] or fluctuating light [25,28,29], because steady-state stomatal conductance measurements cannot reveal sluggishness [25]. Paoletti and Grulke [13] suggested that sluggish stomatal responses may be viewed basically as distinctly retarded stomatal movements under changing environmental conditions. In fact, stomatal conductance responds in general 10-100 times more slowly to changes in conditions than photosynthesis [30]. Ozone-induced ethylene emission has been suggested to affect the sluggish response by reducing stomatal sensitivity to abscisic acid (ABA) [31]. As a consequence of stomatal sluggishness, dynamic controls on tree water loss and stomatal $\mathrm{O}_{3}$ uptake may be impaired [32].

All the above results on sluggishness, however, were obtained with seedlings or saplings under controlled conditions. Relatively high $\mathrm{O}_{3}$ concentrations, potted plants, chamber effects, relatively short duration of most experiments, young tree age and low light are other controlled-condition factors that may affect upscaling of results from juvenile to mature trees [2]. In a Pinus ponderosa forest in California, Grulke et al. [33] reported the lack of stomatal closure at night in early summer which was greater in pole-sized than mature trees; thus there was greater total $\mathrm{O}_{3}$ uptake in pole-sized trees as a result of the greater nocturnal uptake. In mature trees from a US mixed deciduous forest, McLaughlin et al. $[9,34]$ examined hourly to seasonal patterns of environmental parameters, stem growth, and sap flow velocity, and concluded that ambient $\mathrm{O}_{3}$ caused a periodic slowdown in seasonal growth patterns that was attributable in part to amplification of diurnal patterns of water loss in tree stems. This was supported by $\mathrm{O}_{3}$-induced increases in average sap-flow rates over the growing season. Statistically significant increases in whole-tree canopy conductance, depletion of soil moisture in the rooting zone, and reduced late-season streamflow in forested watersheds were concurrently detected in response to increasing ambient $\mathrm{O}_{3}$ levels. In mature Populus spp. trees protected or not by the antiozonant ethylenediurea and exposed to ambient $\mathrm{O}_{3}$ in Italy, Giovannelli et al. [35] found evidence of stomatal sluggishness only in mornings in the summer when the $\mathrm{O}_{3}$-injured trees increased sap flow so that the internal water resources were mobilized during periods of intense evaporative demand. Also, Sun et al. [36] found that stand sap flux of a mixed aspen-birch community in the Aspen $\mathrm{O}_{3}$ FACE increased progressively during the summer relative to ambient air, suggesting increased stomatal opening. Conversely, mature beech trees under free-air fumigation within the stand canopy showed the enhanced $\mathrm{O}_{3}$ regime to reduce crown transpiration and conductance in summer during late-morning through early-afternoon hours [24].

Lack of data on water-use responses of mature trees under enhanced $\mathrm{O}_{3}$ exposure and on the leaf to tree-level integration are major limitations in understanding and modeling responses of forests to environmental changes $[4,7,37]$. To fill these gaps, we aimed at quantifying whole-tree transpiration and leaf-level variable-light (flecky, where sunflecks are rapid changes in light on leaf surfaces) gas exchange 
at Kranzberg Forest, where ambient and twice-ambient $\mathrm{O}_{3}$ regimes had been applied to adult trees of Fagus sylvatica and Picea abies for 8 years [38,39]. Interactions between $\mathrm{O}_{3}$ and other environmental variables that could change transpiration by individual trees were quantified. To investigate the mechanisms of $\mathrm{O}_{3}$ action, we postulated that $\mathrm{O}_{3}$-induced sluggish stomatal responses to fluctuating environmental parameters, namely flecky light, increase short-term water loss from the foliage. Variable light may represent two-thirds of the incident light sums in forest canopies [40] with relevance for productivity. As light intensity may affect sluggishness [41] and light regimes within canopies affect leaf differentiation, we tested sun and shade leaves to explore whether sluggishness has the potential to occur across an entire tree crown.

\section{Materials and Methods}

\subsection{Experimental Design and Environmental Data}

The site was located at Kranzberger Forst near Freising, Germany $\left(48^{\circ} 25^{\prime} \mathrm{N}, 11^{\circ} 39^{\prime}\right.$ E, elevation $485 \mathrm{~m}$ a.s.1.) in a mixed stand of 53 to 60-year-old Norway spruce (Picea abies) and European beech (Fagus sylvatica).

Exposure to above-ambient $\mathrm{O}_{3}$ concentrations was conducted through an $\mathrm{O}_{3}$ FACE employed within the forest canopy [42,43]. Entire crowns were exposed throughout eight growing seasons (2000-2007) to a twice-ambient $\mathrm{O}_{3}$ regime $\left(2 \mathrm{xO}_{3}\right)$ and compared to trees in unchanged ambient air $\left(1 \mathrm{xO}_{3}\right)$ which served as controls. At $2 \mathrm{xO}_{3}$, maximum $\mathrm{O}_{3}$ concentrations were restricted to $150 \mathrm{ppb}$ to prevent the risk of acute $\mathrm{O}_{3}$ injury [42]. A total of eight $\mathrm{O}_{3}$ analyzers were operated across the site, checked each day for consistency across zero lines and spans, and recalibrated as necessary (an average, once a month). Further details about stand and exposure are in [12,39].

In July 2007, four to five dominant trees of each species within each exposure regime were selected as described in [12,39], each individual is regarded as a replicated case study on its own [44]. $1 \mathrm{xO}_{3}$ and $2 \mathrm{xO}_{3}$ trees were in two separated groups. Air temperature, relative humidity of the air, photosynthetic photon flux density and $\mathrm{O}_{3}$ levels were monitored at $24 \mathrm{~m}$ aboveground at top of the canopy (psychro- and baro-transmitter, ThiesClima, Goettingen, Germany; $\mathrm{O}_{3}$ analyzer: ML8811, Monitor Labs, USA). Soil moisture was recorded at 20-cm depth. Environmental data were recorded as 10-min means (DL2e data logger, Delta-T-Devices, Burwell, Cambridge, U.K.). AOT40 was calculated as the sum of $\mathrm{O}_{3}$ concentrations exceeding a threshold of $40 \mathrm{ppb}$ during daylight hours (global radiation $>50 \mathrm{~W} \mathrm{~m}^{-2}$ ) [45] (CLRTAP, 2017).

During the 8th year of free-air fumigation, we carried out this experiment in July 2017 (1st to 31st). Descriptors of environmental conditions during the 31-day experiment are in Figure 1 and Table 1, and show no significant difference of environmental variables between the two $\mathrm{O}_{3}$ regimes, while $\mathrm{O}_{3}$ daily means, $\mathrm{O}_{3}$ daily spikes and AOT40 (hourly values exceeding $40 \mathrm{ppb}$ accumulated over the light hours of the experimental period) were significantly higher at $2 \mathrm{xO}_{3}$. Soil moisture and the other environmental parameters were not limiting for gs of beech and spruce over the experiment.

Table 1. Mean daily environmental parameters ( \pm Standard Error) did not differ between $1 \mathrm{xO}_{3}$ and $2 \mathrm{xO}_{3}$ (t-test, $\mathrm{ns}, p>0.05, n=31$ days). Data are daily values for all parameters except photosynthetic photon flux density (diurnal) for July 2007.

\begin{tabular}{cccc}
\hline Parameter & $\mathbf{1 \times \mathbf { O } _ { 3 }}$ & $\mathbf{2 x O}_{\mathbf{3}}$ & \\
\hline Air temperature $\left({ }^{\circ} \mathrm{C}\right)$ & $18.33 \pm 0.79$ & $17.86 \pm 0.80$ & $\mathrm{~ns}$ \\
Relative humidity $(\%)$ & $71.61 \pm 2.34$ & $71.03 \pm 2.44$ & $\mathrm{~ns}$ \\
Soil water content $(\%)$ & $27.0 \pm 1.0$ & $27.0 \pm 0.9$ & $\mathrm{~ns}$ \\
Vapour pressure deficit $(\mathrm{MPa})$ & $7.87 \pm 0.96$ & $6.66 \pm 0.91$ & $\mathrm{~ns}$ \\
Photosynthetic photon flux density $\left(\mu \mathrm{mol} \mathrm{m}{ }^{-2} \mathrm{~s}^{-1}\right)$ & $876 \pm 52$ & $876 \pm 52$ & $\mathrm{~ns}$ \\
\hline
\end{tabular}




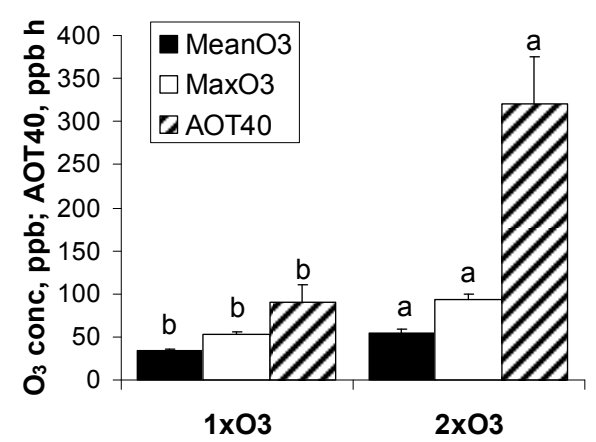

Figure 1. Descriptors of ozone exposure at ambient $\left(1 \mathrm{xO}_{3}\right)$ and twice-ambient ozone $\left(2 \mathrm{xO}_{3}\right)$. Data are daily means of hourly concentrations and accumulated hourly values above 40 ppb (+SE) in July 2007. Different letters show significant differences between the ozone regimes ( $t$-test or Mann-Whitney $\mathrm{U}$ test, $p<0.001, n=31$ days).

\subsection{Assessment of Xylem Sap Flow and Calculation of Whole-Tree Transpiration}

Sap flow was measured with 2-cm long continuously heated sap flow gauges according to Granier [46] at 0-2 cm sapwood depth. Sensors were inserted into the tree xylem at breast height (one sensor each at $\mathrm{S}$ and $\mathrm{N}$-exposure) in beech and spruce trees. Additional sensors at 4 and $6 \mathrm{~cm}$ depth determined the variation in sap flow across the cross-sectional sapwood area of two trees per species. The sapwood area-related flow density at depths beyond $6 \mathrm{~cm}$ was linearly extrapolated towards the heartwood area on the basis of the assessments at 2, 4 and $6 \mathrm{~cm}$ depth. The proportional reductions in sap flow with increasing depths were used to express the sap flow density across the entire cross-sectional sapwood area in relation to the sensor readings at $2 \mathrm{~cm}$ depth. The relationship was adapted to all study trees in each species. The cross-sectional sapwood area was derived from increment cores of neighboring trees with DBH similar to that of the study trees. The product of sap flow density and cross-sectional sapwood area at breast height rendered whole-tree transpiration. Sap flow data were recorded as 10-min means, at the same intervals as environmental data. Results are shown for the 31-day experimental period.

\subsection{Assessment of Stomatal Responses to Fleck Light}

$\mathrm{As}_{3}$ resulted to be a significant factor affecting transpiration only in beech (Table 2), leaf-level gas exchange was measured at 8-13 CET only in this species, by means of an open-flow gas analyzer (Li-6400; Li-Cor, Inc., Lincoln NE, USA), recording data every $30 \mathrm{~s}$. Twelve leaves (six sun leaves at top of the crown and 6 shade leaves at $2 \mathrm{~m}$ below the top) per beech tree, three trees per each of the two $\mathrm{O}_{3}$ regimes, were selected for experimental manipulation of light. Leaves were free of visible injury on the 3rd to 5th position from the shoot tip. According to [25], light levels were alternated between 1500 and $100 \mu \mathrm{mol} \mathrm{m}^{-2} \mathrm{~s}^{-1}$, waiting for stomatal adjustment after each light level. Full adjustment was established at two consecutive minutes of stable stomatal conductance (gs). Steady-state in practice means that gs showed no systematic decrease or increase $( \pm 2 \%)$ over a $2 \mathrm{~min}$ period. The treatment was repeated two times, under constant leaf-to-air vapour pressure deficit $(<2 \mathrm{kPa})$. Descriptors of gas exchange responses to light manipulation were calculated as average of the two cycles per leaf: maximum and minimum gs and photosynthesis (A); span of gs and A variation, as difference between maximum and minimum values; time gs and $\mathrm{A}$ reached equilibrium when stomata closed and opened; error in recording gs at the time A reached equilibrium, calculated as percent of steady-state gs; cumulated water loss and stomatal $\mathrm{O}_{3}$ uptake, calculated as $\sum_{k=1}^{n}\left(\mathrm{~V}_{\mathrm{k}}-\mathrm{V}_{\mathrm{eq}}\right) * 30$ s during closing, and as $\sum_{k=1}^{n}\left(\mathrm{~V}_{\text {eq }}-\mathrm{V}_{\mathrm{k}}\right) * 30$ s during opening, where $\mathrm{V}_{\mathrm{k}}$ is the mean value of each 30 -s interval and $\mathrm{V}_{\text {eq }}$ is the value at equilibrium. Water loss was calculated as mmol of transpired $\mathrm{H}_{2} \mathrm{O}$ per leaf $\mathrm{m}^{2}$. Assuming that $\mathrm{O}_{3}$ concentrations inside the mesophyll approach zero [47], stomatal $\mathrm{O}_{3}$ uptake was calculated by converting gs into stomatal conductance for $\mathrm{O}_{3}$ and multiplying times the concurrent $\mathrm{O}_{3}$ concentrations in ambient air [48]. 


\subsection{Data Analysis}

Data were checked for normal distribution (Kolmogorov-Smirnov D test). A one-way analysis of variance (ANOVA) was applied to environmental and $\mathrm{O}_{3}$ data, with the $\mathrm{O}_{3}$ regime as a factor. Differences between regimes were tested by a t-test for normally distributed variables and by a non parametric Mann-Whitney $\mathrm{U}$ test for non-normally distributed variables, i.e., daily means of $\mathrm{O}_{3}$ peaks and AOT40. A two-way ANOVA was applied to transpiration data, with $\mathrm{O}_{3}$ regime $\left(1 \mathrm{xO}_{3}\right.$ vs. $\left.2 \mathrm{xO}_{3}\right)$ and tree species (beech vs. spruce) as factors. A two-way ANOVA was applied to data from fleck light responses, with $\mathrm{O}_{3}$ regime $\left(1 \mathrm{xO}_{3}\right.$ vs. $\left.2 \mathrm{xO}_{3}\right)$ and leaf type (sun vs. shade) as factors. Linear correlations among all the variables were tested. The effects of $\mathrm{O}_{3}$ on transpiration were tested between lines for colinearity [49]. Stepwise multiple regressions were applied to consider concurrent influences of the daily means of 10-min $\mathrm{O}_{3}$ means (ozavg), $\mathrm{O}_{3}$ peaks (ozmax), vapour pressure difference means (vpd_avg), VPD peaks (vpd_max), air temperature means (t_avg), air temperature peaks (t_max), photosynthetic photon flux density means (ppfd), and to identify the variables that most significantly influenced daily transpiration in beech and spruce in the two $\mathrm{O}_{3}$ regimes. Tests of significance were made at a $95 \%$ confidence level. Data were processed using the STATISTICA 10.0 package for Windows (StatSoft, Tulsa, OK, USA).

\section{Results}

\subsection{Tree-Level Transpiration}

Sap-flow measurements showed that daily total transpiration increased with increasing daily $\mathrm{O}_{3}$ concentrations (both mean and max), in both species (Figure 2, Table 3). The correlation was not significant at $1 \mathrm{xO}_{3}$ in beech, so that slope and intercept of the $1 \mathrm{xO}_{3}$ and $2 \mathrm{xO}_{3}$ correlation lines were not compared while they significantly differed in spruce (Figure 2). In spruce, transpiration was more sensitive to $\mathrm{O}_{3}$ at $1 \mathrm{xO}_{3}$ than at $2 \mathrm{xO}_{3}$ as supported by a higher slope. To explain this surprising result, we focused on the environmental parameters, as other-than- $\mathrm{O}_{3}$ factors may have affected this result. Although environmental parameters were similar at $1 \mathrm{xO}_{3}$ and $2 \mathrm{xO}_{3}$ (Table 1), most of the investigated variables (daily means of 10-min transpiration, $\mathrm{O}_{3}$ means, $\mathrm{O}_{3}$ peaks, VPD means, VPD peaks, air temperature means, air temperature peaks, photosynthetic flux density means) were inter-correlated, with the notable exception of (mean and peak) $\mathrm{O}_{3}$ and beech transpiration at $1 \mathrm{xO}_{3}$ (Table 3). A multiple linear stepwise regression was thus applied to quantify the relative contribution of each factor to transpiration. The main factors affecting transpiration were light (in both species and $\mathrm{O}_{3}$ regimes) and VPD (in spruce) (Table 2). Ozone peaks affected transpiration (5-8\% of the variance) only in beech.
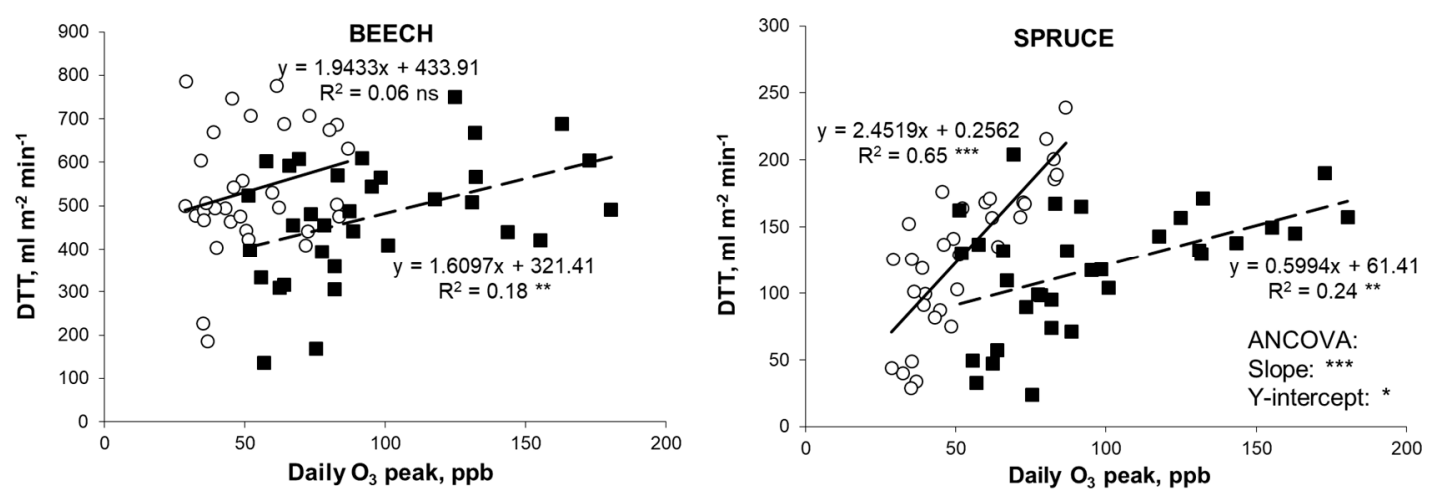

Figure 2. Daily total transpiration (DTT) increased with increasing daily ozone peaks in mature trees of European beech and Norway spruce exposed to ambient ( $\bigcirc$ solid line) and twice-ambient $\mathrm{O}_{3}$ regimes (घ, dashed line) (July 2007). Each point is the average of $4-5$ trees. Asterisks show the significance of the analysis: ${ }^{* *}, p<0.001 ; * *, p<0.01 ; *, p<0.05 ; \mathrm{ns}, p \geq 0.05$. 
Table 2. Summary of a stepwise multiple linear regression to quantify the effects of the daily 10-min means of $\mathrm{O}_{3}$ concentrations (ozavg), $\mathrm{O}_{3}$ peaks (ozmax), vapour pressure difference means (vpd_avg), VPD peaks (vpd_max), air temperature means (t_avg), air temperature peaks (t_max), photosynthetic photon flux density means (ppfd), on mean daily total transpiration in beech at spruce at different ozone regimes. Bold $p$ values are significant at $p<0.05$.

\begin{tabular}{|c|c|c|c|c|c|}
\hline Regression & Variables & Multiple $R^{2}$ & Variance Explained at Each Step, \% & F & $p$-Level \\
\hline \multicolumn{6}{|l|}{$1 \mathrm{xO}_{3}$ beech } \\
\hline & ppfd & 0.32 & 32 & 14.26 & 0.0007 \\
\hline & 1xozmax & 0.40 & 8 & 3.97 & 0.0556 \\
\hline & vpd_avg & 0.43 & 3 & 1.69 & 0.2034 \\
\hline & t_avg & 0.48 & 5 & 2.89 & 0.1000 \\
\hline & t_max & 0.53 & 5 & 2.86 & 0.1024 \\
\hline \multicolumn{6}{|l|}{$1 \times \mathrm{O}_{3}$ spruce } \\
\hline & vpd_max & 0.84 & 84 & 167.09 & $<0.0001$ \\
\hline & ppfd & 0.88 & 4 & 10.67 & 0.0027 \\
\hline & t_max & 0.90 & 2 & 5.08 & 0.0319 \\
\hline & vpd_avg & 0.91 & 1 & 3.45 & 0.0738 \\
\hline & t_avg & 0.92 & 1 & 4.26 & 0.0487 \\
\hline \multicolumn{6}{|l|}{$2 \mathrm{xO}_{3}$ beech } \\
\hline & ppfd & 0.54 & 54 & 36.03 & $<0.0001$ \\
\hline & 2xozmax & 0.62 & 5 & 3.84 & 0.0596 \\
\hline & 2xozavg & 0.57 & 3 & 1.90 & 0.1778 \\
\hline \multicolumn{6}{|l|}{$2 \mathrm{xO}_{3}$ spruce } \\
\hline & ppfd & 0.79 & 79 & 120.17 & $<0.0001$ \\
\hline & t_max & 0.85 & 6 & 11.74 & 0.0018 \\
\hline & vpd_avg & 0.86 & 1 & 2.07 & 0.1611 \\
\hline & t_avg & 0.88 & 2 & 3.04 & 0.0924 \\
\hline & vpd_max & 0.91 & 3 & 8.30 & 0.0077 \\
\hline
\end{tabular}

When analyzing total transpiration with $\mathrm{O}_{3}$ regime as a factor, the $2 \mathrm{xO}_{3}$ regime did not induce a significant reduction in transpiration (Figure 3). The reduction was in agreement with $2 \mathrm{xO}_{3}$ leaf-level steady-state measurements showing lower gs than $1 \mathrm{xO}_{3}$ (Figure $4 \mathrm{~A}$ ).

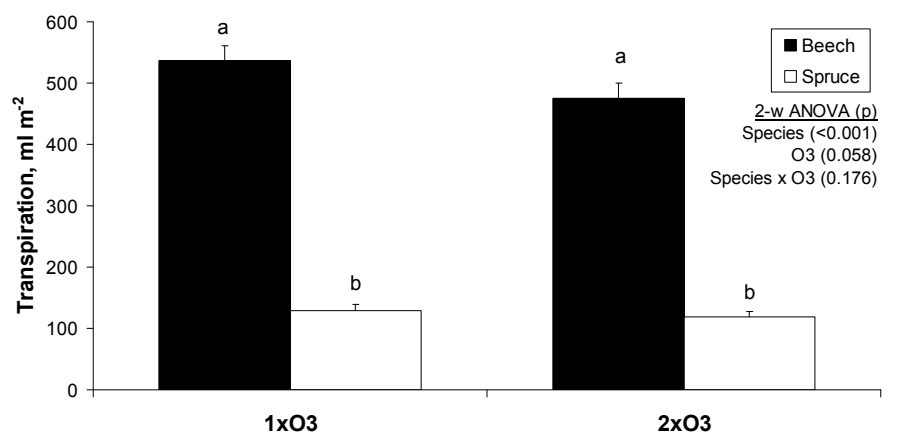

Figure 3. Mean daily total transpiration $( \pm S E)$ calculated from sap flow measurements in beech and spruce trees. Each bar is the average of $4-5$ trees in 31 days (July 2007). The inset shows the levels of significance from a two-way (tree species $\mathrm{x}_{3}$ regime) analysis of variance ( $n=31$ days). 
Table 3. Correlation coefficient ( $\mathrm{r}$ ) and level of significance $(p)$ in the correlation matrix among daily values of total transpiration in beech (BTr) and spruce (STr) and 10-min means of $\mathrm{O}_{3}$ concentrations (ozavg), $\mathrm{O}_{3}$ peaks (ozmax), vapour pressure difference means (vpd_avg), vapour pressure deficit peaks (vpd_max), air temperature means (t_avg), air temperature peaks (t_max), photosynthetic photon flux density means (ppfd) at ambient (1x) and twice-ambient ozone ( $2 x)$. Bold $p$ values are significant at $p<0.05$.

\begin{tabular}{|c|c|c|c|c|c|c|c|c|c|c|c|c|c|}
\hline & $1 \times B T r$ & $1 x S T r$ & 1xOzavg & 1xOzmax & $2 \times B \operatorname{Tr}$ & $2 \times S T r$ & 2 xozavg & $2 x O z m a x$ & Vpd_Avg & Vpd_Max & t_Avg & t_Max & Ppfd \\
\hline $1 \times B T r$ & $\begin{array}{l}1.0000 \\
p=-\end{array}$ & & & & & & & & & & & & \\
\hline $1 \mathrm{xSTr}$ & $\begin{array}{c}r=0.5951 \\
p<0.001\end{array}$ & $\begin{array}{l}1.0000 \\
p=-\end{array}$ & & & & & & & & & & & \\
\hline 1xozavg & ns & $\begin{array}{c}\mathrm{r}=0.7631 \\
p<0.001\end{array}$ & $\begin{array}{c}\mathrm{r}=1.0000 \\
p=-\end{array}$ & & & & & & & & & & \\
\hline 1xozmax & ns & $\begin{array}{c}\mathrm{r}=0.8052 \\
p<0.001\end{array}$ & $\begin{array}{c}r=0.9153 \\
p<0.001\end{array}$ & $\begin{array}{c}\mathrm{r}=1.0000 \\
p=-\end{array}$ & & & & & & & & & \\
\hline $2 \times B T r$ & $\begin{array}{c}r=0.8815 \\
p<0.001\end{array}$ & $\begin{array}{c}\mathrm{r}=0.7909 \\
p<0.001\end{array}$ & $\begin{array}{c}\mathrm{r}=0.5012 \\
p=0.003\end{array}$ & $\begin{array}{c}r=0.4664 \\
p=0.006\end{array}$ & $\begin{array}{l}1.0000 \\
p=-\end{array}$ & & & & & & & & \\
\hline $2 \mathrm{xSTr}$ & $\begin{array}{c}\mathrm{r}=0.6790 \\
p<0.001\end{array}$ & $\begin{array}{c}\mathrm{r}=0.9743 \\
p<0.001\end{array}$ & $\begin{array}{c}\mathrm{r}=0.6916 \\
p<0.001\end{array}$ & $\begin{array}{c}r=0.7399 \\
p<0.001\end{array}$ & $\begin{array}{c}\mathrm{r}=0.8132 \\
p<0.001\end{array}$ & $\begin{array}{l}1.0000 \\
p=-\end{array}$ & & & & & & & \\
\hline 2xozavg & ns & $\begin{array}{c}\mathrm{r}=0.4383 \\
p=0.011\end{array}$ & $\begin{array}{c}\mathrm{r}=0.5850 \\
p<0.001\end{array}$ & $\begin{array}{c}\mathrm{r}=0.5000 \\
p=0.003\end{array}$ & $\begin{array}{c}\mathrm{r}=0.4719 \\
p=0.006\end{array}$ & $\begin{array}{c}\mathrm{r}=0.3502 \\
p=0.046\end{array}$ & $\begin{array}{l}1.0000 \\
p=-\end{array}$ & & & & & & \\
\hline 2 xozmax & ns & $\begin{array}{c}\mathrm{r}=0.5874 \\
p<0.001\end{array}$ & $\begin{array}{c}r=0.6790 \\
p<0.001\end{array}$ & $\begin{array}{c}r=0.7152 \\
p<0.001\end{array}$ & $\begin{array}{c}\mathrm{r}=0.4270 \\
p=0.013\end{array}$ & $\begin{array}{c}\mathrm{r}=0.4919 \\
p=0.004\end{array}$ & $\begin{array}{c}r=0.8724 \\
p<0.001\end{array}$ & $\begin{array}{l}1.0000 \\
p=-\end{array}$ & & & & & \\
\hline vpd_avg & $\begin{array}{c}\mathrm{r}=0.4640 \\
p=0.007\end{array}$ & $\begin{array}{c}\mathrm{r}=0.9038 \\
p<0.001\end{array}$ & $\begin{array}{c}r=0.8138 \\
p<0.001\end{array}$ & $\begin{array}{c}r=0.8202 \\
p<0.001\end{array}$ & $\begin{array}{c}r=0.6423 \\
p<0.001\end{array}$ & $\begin{array}{c}r=0.8628 \\
p<0.001\end{array}$ & $\mathrm{~ns}$ & $\begin{array}{c}\mathrm{r}=0.4613 \\
p=0.007\end{array}$ & $\begin{array}{l}1.0000 \\
p=-\end{array}$ & & & & \\
\hline vpd_max & $\begin{array}{c}\mathrm{r}=0.4433 \\
p=0.010\end{array}$ & $\begin{array}{c}\mathrm{r}=0.9184 \\
p<0.001\end{array}$ & $\begin{array}{c}\mathrm{r}=0.8199 \\
p<0.001\end{array}$ & $\begin{array}{c}r=0.8689 \\
p<0.001\end{array}$ & $\begin{array}{c}\mathrm{r}=0.6450 \\
p<0.001\end{array}$ & $\begin{array}{c}\mathrm{r}=0.8648 \\
p<0.001\end{array}$ & $\begin{array}{c}r=0.4627 \\
p=0.007\end{array}$ & $\begin{array}{c}r=0.6013 \\
p<0.001\end{array}$ & $\begin{array}{c}r=0.9503 \\
p<0.001\end{array}$ & $\begin{array}{l}1.0000 \\
p=-\end{array}$ & & & \\
\hline t_avg & ns & $\begin{array}{c}\mathrm{r}=0.8545 \\
p<0.001\end{array}$ & $\begin{array}{c}\mathrm{r}=0.8297 \\
p<0.001\end{array}$ & $\begin{array}{c}\mathrm{r}=0.8430 \\
p<0.001\end{array}$ & $\begin{array}{c}\mathrm{r}=0.5005 \\
p<0.001\end{array}$ & $\begin{array}{c}\mathrm{r}=0.7798 \\
p<0.001\end{array}$ & $\begin{array}{c}\mathrm{r}=0.4029 \\
p=0.020\end{array}$ & $\begin{array}{c}\mathrm{r}=0.5424 \\
p=0.001\end{array}$ & $\begin{array}{c}\mathrm{r}=0.8803 \\
p<0.001\end{array}$ & $\begin{array}{c}\mathrm{r}=0.8986 \\
p<0.001\end{array}$ & $\begin{array}{l}1.0000 \\
p=-\end{array}$ & & \\
\hline t_max & $\begin{array}{c}\mathrm{r}=0.3311 \\
p=0.060\end{array}$ & $\begin{array}{c}\mathrm{r}=0.9079 \\
p<0.001\end{array}$ & $\begin{array}{c}\mathrm{r}=0.8095 \\
p<0.001\end{array}$ & $\begin{array}{c}\mathrm{r}=0.8632 \\
p<0.001\end{array}$ & $\begin{array}{c}\mathrm{r}=0.5953 \\
p<0.001\end{array}$ & $\begin{array}{c}\mathrm{r}=0.8506 \\
p<0.001\end{array}$ & $\begin{array}{c}\mathrm{r}=0.4546 \\
p=0.008\end{array}$ & $\begin{array}{c}\mathrm{r}=0.6068 \\
p<0.001\end{array}$ & $\begin{array}{c}\mathrm{r}=0.8744 \\
p<0.001\end{array}$ & $\begin{array}{c}\mathrm{r}=0.9420 \\
p<0.001\end{array}$ & $\begin{array}{c}\mathrm{r}=0.9671 \\
p<0.001\end{array}$ & $\begin{array}{l}1.0000 \\
p=-\end{array}$ & \\
\hline ppfd & $\begin{array}{c}\mathrm{r}=0.5613 \\
p=0.001\end{array}$ & $\begin{array}{c}\mathrm{r}=0.8817 \\
p<0.001\end{array}$ & $\begin{array}{c}\mathrm{r}=0.7394 \\
p<0.001\end{array}$ & $\begin{array}{c}r=0.7652 \\
p<0.001\end{array}$ & $\begin{array}{c}\mathrm{r}=0.7332 \\
p<0.001\end{array}$ & $\begin{array}{c}\mathrm{r}=0.8916 \\
p<0.001\end{array}$ & $\begin{array}{c}\mathrm{r}=0.4401 \\
p=0.010\end{array}$ & $\begin{array}{c}\mathrm{r}=0.5622 \\
p<0.001\end{array}$ & $\begin{array}{c}\mathrm{r}=0.8190 \\
p<0.001\end{array}$ & $\begin{array}{c}\mathrm{r}=0.8405 \\
p<0.001\end{array}$ & $\begin{array}{c}\mathrm{r}=0.7096 \\
p<0.001\end{array}$ & $\begin{array}{c}\mathrm{r}=0.7883 \\
p<0.001\end{array}$ & $\begin{array}{l}1.0000 \\
p=-\end{array}$ \\
\hline
\end{tabular}



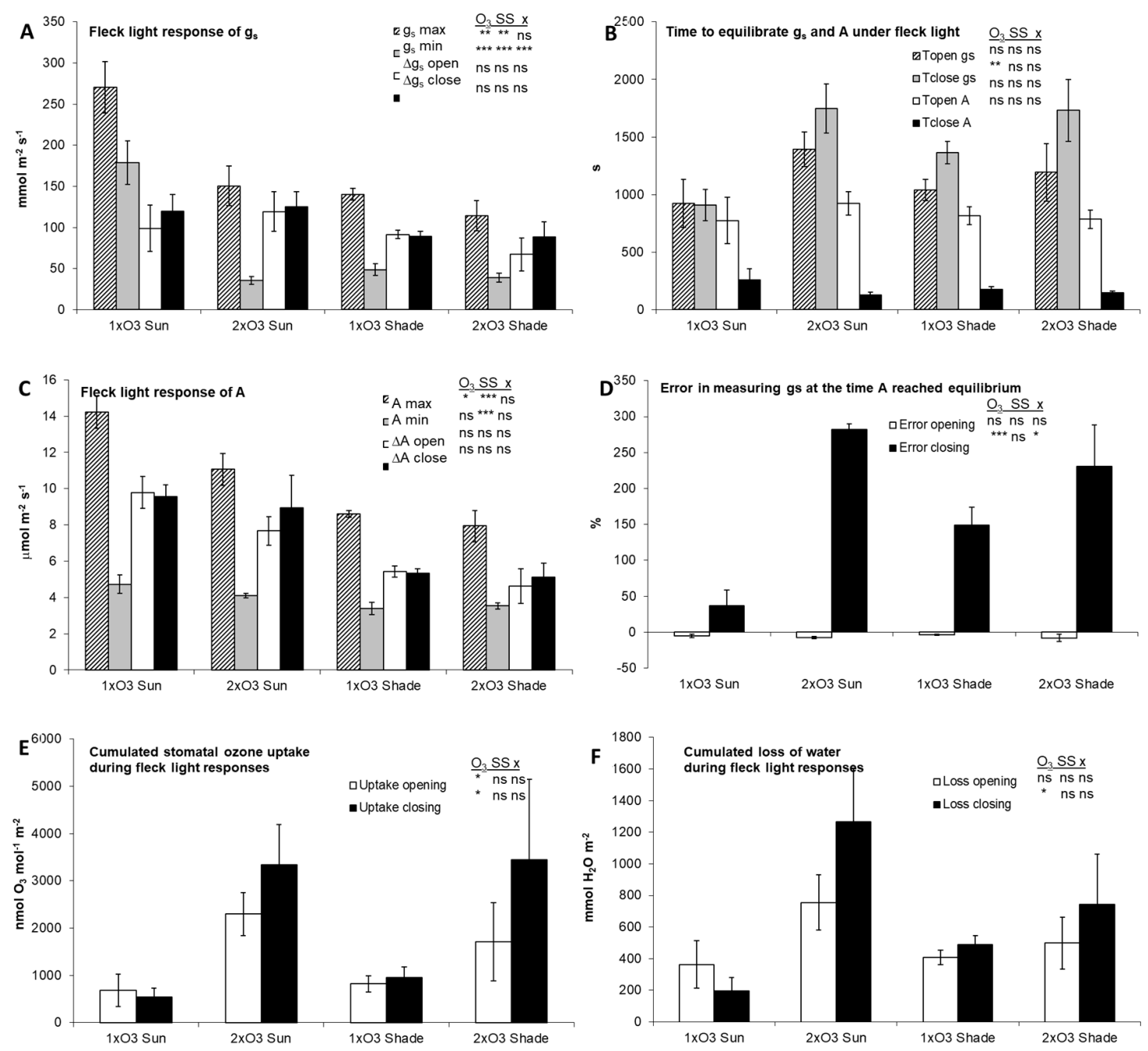

Figure 4. Summary of stomatal and assimilatory responses to fleck light in beech ( \pm SE): (A) max and min stomatal conductance (gs) and span of gs variation $(\Delta)$; (B) time gs and A reached equilibrium when stomata closed and opened (T); (C) max and min photosynthesis (A) and span of A variation $(\Delta)$; (D) error in measuring gs at the time A reached equilibrium when stomata closed and opened (error); (E) relative stomatal ozone uptake during opening and closing (uptake); (F) relative water loss during opening and closing (loss). The insets show the results of a two-way $\left(\mathrm{O}_{3}\right.$ regime $\mathrm{x}$ Sun/Shade leaf) ANOVA: ns, $p>0.05 ;{ }^{*}, p<0.05 ;{ }^{* *}, p<0.01 ;{ }^{* * *}, p<0.001$. Each bar is the average of two cycles on six leaves $(n=6)$.

\subsection{Leaf-Level Flecky Light Responses}

At both $\mathrm{O}_{3}$ regimes, beech stomata were slower in closing (Tclose gs) than in opening (Topen gs), with no significant difference depending on the leaf light exposure level (i.e., sun vs. shade; Figure 4B). The $2 \mathrm{xO}_{3}$ stomata were slower in opening and-in particular-in closing than $1 \mathrm{xO}_{3}$ stomata, again with no significant difference between leaf light exposure level. As a result, cumulated stomatal $\mathrm{O}_{3}$ uptake before stomata reached equilibrium was 1.7 (during opening) and 4.6 times (during closing) greater in $2 \mathrm{xO}_{3}$ leaves than in $1 \mathrm{xO}_{3}$ leaves, both for sun $(+236 \%$ and $+527 \%$, respectively) and shade leaves $\left(+109 \%\right.$ and $+272 \%$, respectively) (Figure $4 \mathrm{E}$ ), while $\mathrm{O}_{3}$ concentrations were just 0.6 times greater at $2 \mathrm{xO}_{3}$ than that at $1 \mathrm{xO}_{3}$ (Figure 1). Cumulated water loss during stomatal adjustment was also greater at $2 \mathrm{xO}_{3}$ than at $1 \mathrm{xO}_{3}$, although the difference was significant only during stomata closing (Figure $4 \mathrm{~F}$ ). Shade and sun leaves showed similar responses, except for the maximum and minimum values of gs and $\mathrm{A}$, which were lower in shade leaves (Figure $4 \mathrm{~A}, \mathrm{C}$ ). A number of unresponsive $2 \mathrm{xO}_{3}$ leaves were detected. After shutting down, the stomata of unresponsive leaves did not reopen regularly (Figure 5). 
Data from unresponsive leaves were discarded because a steady state was not reached. If gs was recorded at the time A reached an equilibrium, an error was generated (Figures $4 \mathrm{D}$ and 6). This error was larger when measurements were carried out from high to low light (on average, $+174 \%$ ) than from low to high light $(-6 \%)$. This error was much larger in $2 \mathrm{xO}_{3}$ leaves $(+256 \%$ and $-8 \%$ during closing and opening, respectively) than in $1 \mathrm{xO}_{3}$ leaves (+93\% and $\left.-5 \%\right)$. The error during stomatal closure was higher in shade than sun leaves at $1 \mathrm{xO}_{3}(230 \%$ vs. $282 \%)$ and vice versa at $2 \mathrm{xO}_{3}(149 \%$ vs. $37 \%)$.

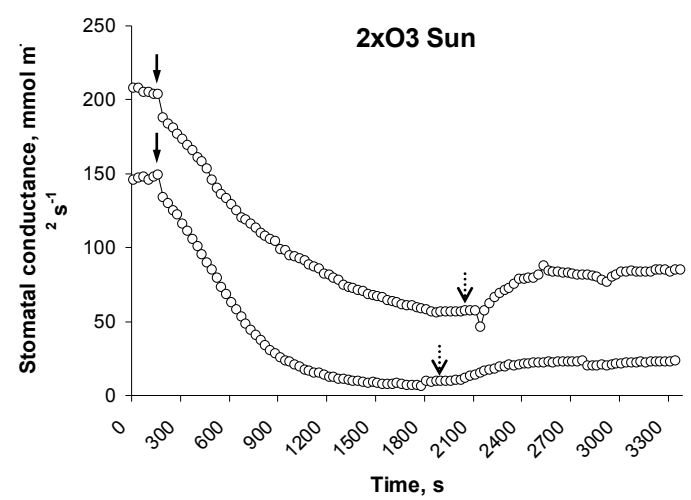

Figure 5. Examples of unresponsive $2 \mathrm{xO}_{3}$ beech leaves. Stomata closed regularly when the light was off (full arrows) but did not re-open when the light was on (dotted arrows).
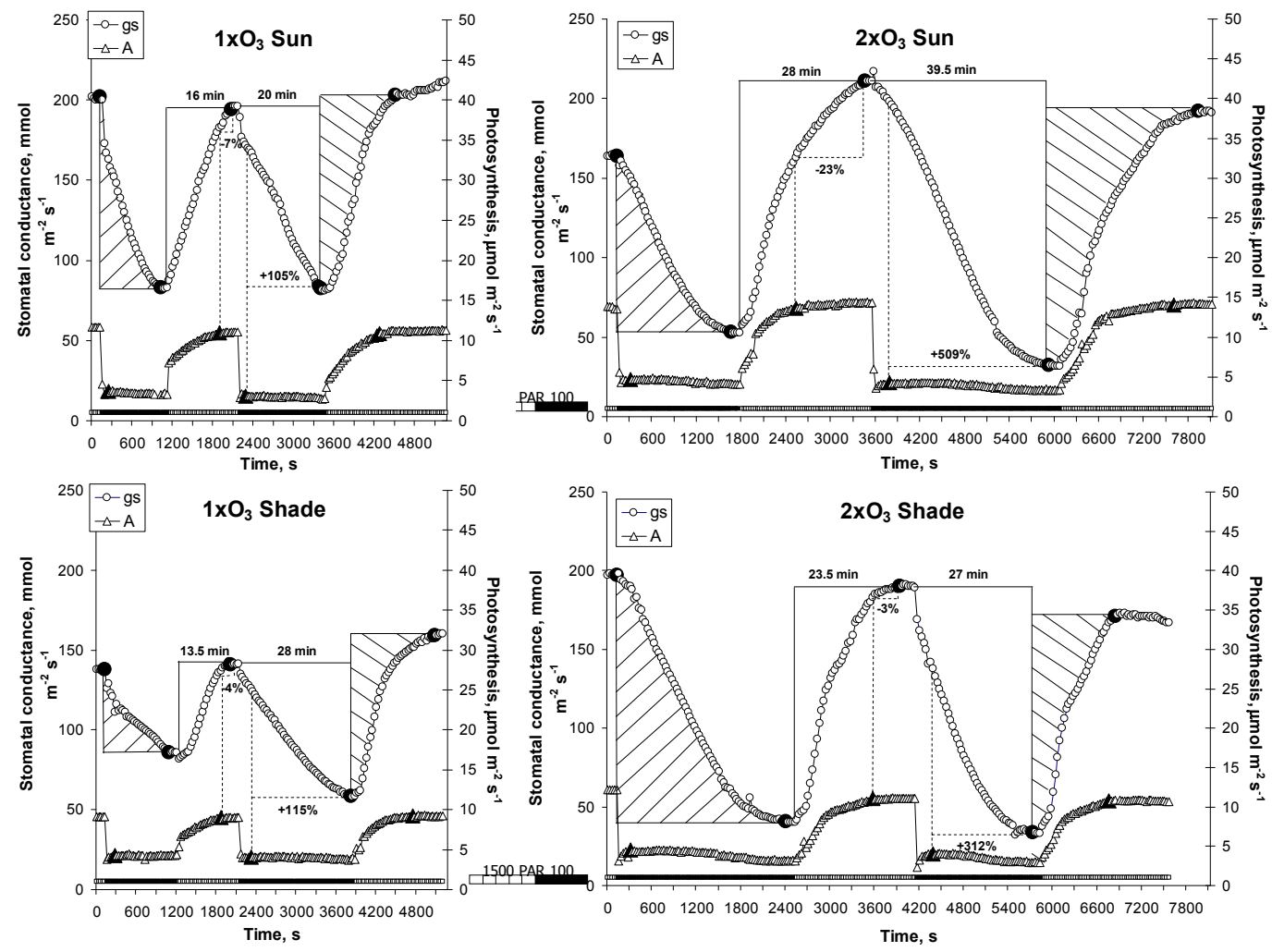

Figure 6. Example of fleck light responses in sun and shade leaves of beech trees. When stomatal conductance (gs) achieved equilibrium, the light intensity was sharply decreased from 1500 to $100 \mu \mathrm{mol} \mathrm{m}{ }^{-2} \mathrm{~s}^{-1}$ until equilibrium, and then increased again. The treatment was repeated two times. Full symbols show the time equilibrium was reached, i.e., gs or A (photosynthesis) values were stable in the following two minutes. Full lines show examples of calculation of the time to open and to close stomata (in min). Dotted lines show examples of calculation of the error in recording gs at the time A reached equilibrium (as percent of steady-state gs). Slashed surfaces show examples of cumulated water loss and stomatal $\mathrm{O}_{3}$ uptake when stomata closed $(/)$ and opened $(\backslash)$. 


\section{Discussion}

\subsection{Responses of Tree-Level Transpiration}

By regulating evapotranspiration, forests play a key role in the global hydrologic cycle [50] and how $\mathrm{O}_{3}$ affects transpiration via stomata is thus critical to modeling efforts [13]. Drought stress has often been reported to mitigate the negative impacts of $\mathrm{O}_{3}$ on young tree physiology and growth under controlled conditions [11,51-53]. However, empirical evidence from mature trees including physiological $[33,35,54]$ and growth measurements $[9,34]$ suggests that drought effects are exacerbated, not reduced, by the combination with elevated $\mathrm{O}_{3}$, which would challenge forest capacity to buffer extreme hydrological events [36]. To investigate the reasons for this dichotomy, we measured whole-tree transpiration of mature beech and spruce trees that had been exposed for 8 years to ambient and twice-ambient $\mathrm{O}_{3}$ regimes. Over the 31 days of our summer study, mean daily total transpiration did not vary with the $\mathrm{O}_{3}$ regime, because the slight reductions from $1 \mathrm{xO}_{3}$ to $2 \mathrm{xO}_{3}(-11 \%$ in beech and $-8 \%$ in spruce) were not significant, although a tendency was found ( $p=0.058)$. Our current study conducted in 2007 contrasted with findings by Matyssek et al. [24] during the summer months of 2006, reporting on distinct decreases of crown-level transpiration and conductance around noon in beech under $2 \mathrm{xO}_{3}$, suggesting a major role of environmental factors in regulating $\mathrm{O}_{3}$ impacts.

When individual daily values were correlated with daily $\mathrm{O}_{3}$ peaks, daily transpiration was found to increase with increasing daily values of $\mathrm{O}_{3}$ in both species (but insignificant in beech at $1 \times \mathrm{O}_{3}$ ). An analysis carried out with mean $\mathrm{O}_{3}$ values and non-linear approaches gave very similar results (not shown). However, $\mathrm{O}_{3}$ levels are known to co-vary with a number of environmental factors (e.g., VPD, SWC; [55] that may remarkably affect plant transpiration as confirmed in our experiment. A multiple linear regression demonstrated the role of $\mathrm{O}_{3}$ in affecting transpiration in beech $(5-8 \%$ of the total variance) but not in spruce. Such species-specific differential responses are typical of $\mathrm{O}_{3}[56,57]$. In particular, spruce is usually considered more $\mathrm{O}_{3}$-tolerant than beech [58] as it is the case for most conifers, characterized by lower gas exchange and $\mathrm{O}_{3}$ uptake and higher antioxidant capacity than broadleaf trees. A meta-analysis by Li et al. [5] found that the plant functional type has a major role in affecting the growth, physiological, and biochemical responses of woody species to $\mathrm{O}_{3}$.

\subsection{Steady-State and Dynamic Responses of Leaf-Level Gas Exchange (Sun/Shade)}

It is well known that stomata close because of higher intercellular $\mathrm{CO}_{2}$ concentration following $\mathrm{O}_{3}$ attack to the photosynthetic membranes [5]. In our beech experiment, the responses of steady-state gs and $\mathrm{A}$ to $\mathrm{O}_{3}$ varied in tandem, suggesting coupling and decrease of transpiration and carbon assimilation, although effects on the latter were minor [59]. Several previous studies found an uncoupling of gs and $\mathrm{A}$ under $\mathrm{O}_{3}$, in that $\mathrm{A}$ decreased and gs did not vary [17-21,60]. The even higher decline of steady-state gs $(-44 \%$ and $-19 \%$ in sun and shade leaves, respectively; in consistency with Matyssek et al. [24]) than of $\mathrm{A}(-21 \%$ and $-11 \%)$ when comparing $2 \mathrm{xO}_{3}$ with $1 \mathrm{xO}_{3}$ leaves, is the result of the rather long time we waited before actual steady-state of gs was reached: 15-17 min to open and 15-25 min to close at $1 \mathrm{xO}_{3}$ and 23-20 min to open and 29-29 min to close at $2 \mathrm{xO}_{3}$ in sun-shade leaves. Equilibrium of $\mathrm{A}$, in fact, required shorter times, namely 13-14 min to open and 4-3 min to close at $1 \mathrm{xO}_{3}$ and 15-13 min to open and 2-2 min to close at $2 \mathrm{xO}_{3}$ in sun-shade leaves. These results are in agreement with Morison [30] that stomata require more time to reach equilibrium than A. Recording gs when A reaches equilibrium, however, it is a common practice. In response to flecky light, this practice may generate significant overestimations of gs when measurements are carried out during stomatal closing movement ( $\mathrm{ab} .90 \%$ at $1 \mathrm{xO}_{3}$ ), and especially when stomatal responses to enhanced $\mathrm{O}_{3}$ exposure are investigated (ab. $250 \%$ at $2 \mathrm{xO}_{3}$ ). Such delay in stomatal responsiveness suggests caution when assessing gs under $\mathrm{O}_{3}$ pollution. Steady-state $\mathrm{A}$ is typically measured within 2-5 min from changing conditions [61,62], because longer measurement times would affect the steady-state activation of Rubisco and introduce errors [61]. Parameterizing gs is a pillar of flux-based $\mathrm{O}_{3}$ risk assessment for 
vegetation $[63,64]$. Therefore, we recommend separate recordings i.e., first for steady-state $\mathrm{A}$ and then for steady-state gs, especially when leaves are exposed to $\mathrm{O}_{3}$.

Timespans of gs equilibration confirmed a significant slowdown of the stomatal dynamics at elevated $\mathrm{O}_{3}$ [25]. During such extended periods, stomata absorbed more $\mathrm{O}_{3}$ (3.4 and 2.1 times to open and 6.3 and 3.6 times to close in sun and shade leaves, respectively) and lost more water (2.1 and 1.2 times to open and 6.4 and 1.5 times to close in sun and shade leaves, respectively) than the rapidly responding stomata in ambient $\mathrm{O}_{3}\left(1 \times \mathrm{O}_{3}\right)$. Thus, modeling uptake and effects of future $\mathrm{O}_{3}$ pollution may result in underestimation if stomatal sluggishness is not considered [20]. The ecological consequences of these sluggish stomatal responses were estimated for carbon and water balance of deciduous temperate forests at global scale: enhanced $\mathrm{O}_{3}$ was suggested to decrease instantaneous water use efficiency, i.e., the ratio of net $\mathrm{CO}_{2}$ assimilation to transpiration, up to $20 \%$ when stomatal sluggishness is considered, and up to only $5 \%$ when absent [32]. Such an $\mathrm{O}_{3}$-induced decoupling of $\mathrm{A}$ and gs implies that $\mathrm{O}_{3}$ affects gross primary productivity more than transpiration [60]. We postulate that the extra loss of water during sluggish stomatal responses offset part of the reduction in transpiration due to lower steady-state gs. The combination of the two contrasting stomatal phenomena translated into a modest $11 \%$ reduction of transpiration in beech at $2 \mathrm{xO}_{3}$ relative to $1 \mathrm{xO}_{3}$, while steady-state gs decreased by $44 \%$ in sun leaves and $19 \%$ in shade leaves (cf. [24]).

Following Giovannelli [35], longer stomatal opening may increase sap flow and mobilizing the internal water resources in the stem, especially during summer periods with high evaporative demand. Stem water reserves (mainly from phloem and living bark along with capacities from the xylem body) are able to support daily transpiration by 8 to $20 \%$ in mature trees $[65,66]$. This sluggish response supports the hypothesis that $\mathrm{O}_{3}$ pollution amplifies water deficits in forest trees $[33,34,54]$. However, a means of buffering uncontrolled water loss by sluggish stomata leaves in premature shedding of severely injured leaves [67]. We did not assess leaf shedding in our study, although autumnal leaf shedding was accelerated annually to the variable extent under $2 \mathrm{xO}_{3}$ throughout the eight-year experiment [42]. Additional buffering of water loss factor may be provided by unresponsive leaves that did not reopen their stomata after shutting down. Understanding the mechanisms of stomatal responsiveness under $\mathrm{O}_{3}$ stress will help the upscaling of stomatal responses to $\mathrm{O}_{3}$ from the leaf to the tree crown and regional level [48].

Gas exchange of shade leaves was less responsive to $\mathrm{O}_{3}$ exposure than that of sun leaves (in this experiment, but see also [58]). In addition, sluggishness is enhanced at high light availability [41]. Nevertheless, our hypothesis that stomatal sluggishness occurred only in the peripheral crown needs to be rejected. Sluggish responses were similar between $\mathrm{O}_{3}$ regimes and leaf types, and in the absence of significant interactions. We conclude that sluggishness may occur across an entire crown, independently on the leaf type.

\section{Conclusions}

Stomatal sluggishness occurred under $\mathrm{O}_{3}$ stress across entire crowns, independent of leaf type. Hence, short-term water loss from mature beech trees was amplified by slowed stomatal dynamics, while long-term water loss was restricted because of decreased steady-state stomatal conductance. Over the short term of our observations, the two responses appeared to offset each other with a tendency of declining whole-tree transpiration. Whether stomatal sluggishness is a means for buffering gs decline and, hence, mobilizing internal water resources, or a collateral effect of $\mathrm{O}_{3}$-perturbed hormonal relationships [31] remains an intriguing question.

The elevated $\mathrm{O}_{3}$ concentrations simulated in our experiment (55 ppb as daily average) are similar to those predicted for large areas of the most polluted world regions by RCP8.5 [68]. Increased water use of mature forest trees under episodically high $\mathrm{O}_{3}$ events may exacerbate the adverse effects of climatic changes on forest growth and hydrology. As climate change increases the risk of drought and flooding, hydrological consequences of contrasting stomatal $\mathrm{O}_{3}$ responses should be evaluated in 
the longer term and for more species, as only beech transpiration was significantly affected by $\mathrm{O}_{3}$ in this experiment.

Author Contributions: Conceptualization, E.P., N.E.G., R.M.; methodology, E.P., N.E.G., R.M.; formal analysis, E.P., N.E.G.; data analysis, E.P., N.E.G., R.M.; writing-original draft preparation, E.P.; writing-review and editing, E.P., N.E.G., R.M; project coordination R.M.; funding acquisition, R.M. All authors have read and agreed to the published version of the manuscript.

Funding: This research was funded by the CASIROZ project ("The carbon sink strength of beech in a changing environment: Experimental risk assessment of mitigation by chronic ozone impact"), funded through European Commission-Research Directorate General, Environment Programme, Natural Resources Management and Services (contract no. EVK2-2002-00165, Ecosystem Vulnerability), and by Integrated Research Center 'SFB 607: Growth and parasite defense-competition for resources in economic plants from agronomy and forestry', funded through Deutsche Forschungsgemeinschaft (DFG). And The APC was funded by the LIFE project MOTTLES (LIFE15 ENV/IT/000183).

Acknowledgments: We acknowledge support by Angela J. Nunn in getting the field measurements of transpiration and meteorological parameters. Soil water content data are courtesy of L. Zimmermann; LWF, climate station 'Kranzberger Forst'.

Conflicts of Interest: The authors declare no conflict of interest.

\section{References}

1. Bonan, G.B. Forests and climate change: Forcings, feedbacks, and the climate benefits of forests. Science 2008, 320, 1444-1449. [CrossRef]

2. Paoletti, E. Ozone impacts on forests. Cab Rev. Perspect. Agric. Vet. Sci. Nutr. Nat. Resour. $2007,2,13$. [CrossRef]

3. Mills, G.; Pleijel, H.; Malley, C.S.; Sinha, B.; Cooper, O.R.; Schultz, M.G.; Neufeld, H.S.; Simpson, D.; Sharps, K.; Feng, Z.; et al. Tropospheric Ozone Assessment Report: Present-day tropospheric ozone distribution and trends relevant to vegetation. Elem. Sci. Anthr. 2018, 6, 47. [CrossRef]

4. Matyssek, R.; Kozovits, A.R.; Wieser, G.; King, J.; Rennenberg, H. Woody-plant ecosystems under climate change and air pollution-response consistencies across zonobiomes? Tree Physiol. 2017, 37, 706-732. [CrossRef] [PubMed]

5. Li, P.; Feng, Z.; Catalayud, V.; Yuan, X.; Xu, Y.; Paoletti, E. A meta-analysis on growth, physiological, and biochemical responses of woody species to ground-level ozone highlights the role of plant functional types. Plant Cell Environ. 2017, 40, 2369-2380. [CrossRef] [PubMed]

6. Grulke, N.E.; Heath, R.L. Ozone effects on plants in natural ecosystems. Plant Biol. 2019, 22, $1435-8603$. [CrossRef] [PubMed]

7. Matyssek, R.; Kozovits, A.R.; Schnitzler, J.; Pretzsch, J.; Dieler, J.; Wieser, G. Forest trees under air pollution as a factor of climate change. In Trees in a Changing Environment; Tausz, M., Grulke, N., Eds.; Plant Ecophysiology; Springer: Berlin/Heidelberg, Germany, 2014; Volume 9, pp. 117-163.

8. Weigt, R.; Haeberle, K.-H.; Roetzer, T.; Matyssek, R. Whole-tree seasonal nitrogen uptake and partitioning in adult Fagus sylvatica L. and Picea abies L. [Karst.] trees exposed to elevated ground-level ozone. Environ. Pollut. 2015, 196, 511-517. [CrossRef]

9. McLaughlin, S.B.; Nosal, M.; Wullschleger, S.D.; Sun, G. Interactive effects of ozone and climate on tree growth and water use in a southern Appalachian forest in the USA. New Phytol. 2007, 174, 109-124. [CrossRef]

10. Matyssek, R.; Wieser, G.; Fleischmann, F.; Grünhage, L. Ozone Research, quo vadis? Lessons from the free-air canopy fumigation experiment at Kranzberg Forest. In Climate Change, Air Pollution and Global Challenges: Understanding and Perspectives from Forest Research; Matyssek, R., Clarke, N., Cudlin, P., Mikkelsen, T.N., Tuovinen, J.-P., Wieser, G., Paoletti, E., Eds.; Developments in Environmental Science 13; Elsevier: Amsterdam, The Netherlands, 2013; pp. 103-129.

11. Kolb, T.E.; Matyssek, R. Limitations and perspectives about scaling ozone impact in trees. Environ. Pollut. 2001, 115, 373-393. [CrossRef]

12. Löw, M.; Herbinger, K.; Nunn, A.J.; Haberle, K.-H.; Leuchner, M.; Heerdt, C.; Werner, H.; Wipfler, P.; Pretzsch, H.; Tausz, M.; et al. Extraordinary drought of 2003 overrules ozone impact on adult beech trees (Fagus sylvatica). Trees 2006, 20, 539-548. [CrossRef] 
13. Paoletti, E.; Grulke, N.E. Does living in elevated $\mathrm{CO}_{2}$ ameliorate tree response to ozone? A review on stomatal responses. Environ. Pollut. 2005, 137, 483-493. [CrossRef] [PubMed]

14. McAinsh, M.R.; Evans, N.H.; Montgomery, L.T.; North, K.A. Calcium signalling in stomatal responses to pollutants. New Phytol. 2002, 153, 441-447. [CrossRef]

15. Paoletti, E.; Grulke, N.E. Ozone exposure and stomatal sluggishness in different plant physiognomic classes. Environ. Pollut. 2010, 158, 2664-2671. [CrossRef] [PubMed]

16. Matyssek, R.; Günthardt-Goerg, M.S.; Keller, T.; Scheidegger, C. Impairment of the gas exchange and structure in birch leaves (Betula pendula) caused by low ozone concentrations. Trees 1991, 5, 5-13. [CrossRef]

17. Grulke, N.E. Physiological responses of ponderosa pine to gradients of environmental stressors. In Oxidant Air Pollution Impacts in the Montane Forests of Southern California; Miller, P.R., McBride, J.R., Eds.; Springer-Verlag: New York, NY, USA, 1999.

18. Paoletti, E.; Nali, C.; Lorenzini, G. Early responses to acute ozone in two Fagus sylvatica clones differing in xeromorphic adaptations: Photosynthetic and stomatal processes, membrane and epicuticular characteristics. Environ. Monit. Assess. 2007, 128, 93-108. [CrossRef] [PubMed]

19. Grulke, N.E.; Paoletti, E.; Heath, R.L. Chronic vs. short-term acute $\mathrm{O}_{3}$ exposure effects on nocturnal transpiration in two Californian oaks. Sci. World J. 2007, 7, 134-140. [CrossRef]

20. Grulke, N.E.; Paoletti, E.; Heath, R.L. Comparison of calculated and measured foliar $\mathrm{O}_{3}$ flux in crop and forest species. Environ. Pollut. 2007, 146, 640-647. [CrossRef]

21. Hoshika, Y.; Carriero, G.; Feng, Z.; Zhang, Y.; Paoletti, E. Determinants of stomatal sluggishness in ozone-exposed deciduous tree species. Sci. Total Environ. 2014, 481, 453-458. [CrossRef]

22. Hoshika, Y.; De Carlo, A.; Baraldi, R.; Neri, L.; Carrari, E.; Agathokleous, E.; Zhang, L.; Fares, S.; Paoletti, E. Ozone-induced impairment of night-time stomatal closure in $\mathrm{O}_{3}$-sensitive poplar clone is affected by nitrogen but not by phosphorus enrichment. Sci. Total Environ. 2019, 692, 713-722. [CrossRef]

23. Matyssek, R.; Gunthardt-Goerg, M.; Maurer, S.; Keller, T. Nighttime exposure to ozone reduces whole-plant production in Betula pendula. Tree Physiol. 1995, 15, 159-165. [CrossRef]

24. Matyssek, R.; Baumgarten, M.; Hummel, U.; Häberle, K.-H.; Kitao, M.; Wieser, G. Canopy-level stomatal narrowing in adult Fagus sylvatica under $\mathrm{O}_{3}$ stress-means of preventing enhanced $\mathrm{O}_{3}$ uptake under high $\mathrm{O}_{3}$ exposure? Environ. Pollut. 2015, 196, 518-526. [CrossRef] [PubMed]

25. Paoletti, E. Ozone slows stomatal response to light and leaf wounding in a Mediterranean evergreen broadleaf, Arbutus unedo. Environ. Pollut. 2005, 134, 439-445. [CrossRef] [PubMed]

26. Patterson, M.T.; Rundel, P.W. Seasonal physiological responses of ozone stressed Jeffrey pine in Sequoia National Park, California. In Effects of Air Pollution on Western Forests; Olson, R.K., Lefohn, A., Eds.; Air and Waste Management Association: Pittsburgh, PA, USA, 1989.

27. Pearson, M.; Mansfield, T.A. Interacting effects of ozone and water stress on the stomatal resistance of beech (Fagus sylvatica L.). New Phytol. 1993, 123, 351-358. [CrossRef]

28. Keller, T.; Häsler, R. The influence of a fall fumigation with ozone on the stomatal behavior of spruce and fir. Oecologia 1984, 64, 284-286. [CrossRef] [PubMed]

29. Reich, P.B.; Lassoie, J.P. Effects of low level ozone exposure on leaf diffusive conductance and water use efficiency caused be air pollutants. Plant Cell Environ. 1984, 7, 661-668. [CrossRef]

30. Morison, J.I.L. Stomatal response to increased $\mathrm{CO}_{2}$ concentration. J. Exp. Bot. 1998, 49, 443-452. [CrossRef]

31. Wilkinson, S.; Davies, W. Drought, ozone, ABA and ethylene: New insights from cell to plant community. Plant Cell Environ. 2010, 33, 510-525. [CrossRef]

32. Hoshika, Y.; Katata, G.; Deushi, M.; Watanabe, M.; Koike, T.; Paoletti, E. Ozone-induced stomatal sluggishness changes carbon and water balance of temperate deciduous forests. Sci. Rep. 2016, 5, 9871. [CrossRef]

33. Grulke, N.E.; Alonso, R.; Nguyen, T.; Cascio, C.; Dobrowolski, W. Stomata open at night in pole-sized and mature ponderosa pine: Implications for $\mathrm{O}_{3}$ exposure metrics. Tree Physiol. 2004, 24, 1001-1010. [CrossRef]

34. McLaughlin, S.B.; Wullschleger, S.D.; Sun, G.; Nosal, M. Interactive effects of ozone and climate on water use, soil moisture content and streamflow in a southern Appalachian forest in the USA. New Phytol. 2007, 174, 125-136. [CrossRef]

35. Giovannelli, A.; Traversi, M.L.; Anichini, M.; Hoshika, Y.; Fares, S.; Paoletti, E. Effect of long-term vs. short-term ambient ozone exposure on radial stem growth, sap flux and xylem morphology of $\mathrm{O}_{3}$-sensitive poplar trees. Forests 2019, 10, 396. [CrossRef] 
36. Sun, G.; Mclaughlin, S.M.; Porter, J.H.M.; Uddling, J.; Mulholland, P.J.; Adams, M.B.; Pederson, N. Interactive influences of ozone and climate on streamflow of forested watersheds. Glob. Chang. Biol. 2012, 18, 3395-3409. [CrossRef]

37. Hoshika, Y.; Watanabe, M.; Carrari, E.; Paoletti, E.; Koike, T. Ozone-induced stomatal sluggishness changes stomatal parameters of Jarvis-type model in white birch and deciduous oak. Plant Biol. 2018, 20, $20-28$. [CrossRef] [PubMed]

38. Matyssek, R.; Bahnweg, G.; Ceulemans, R.; Fabian, P.; Grill, D.; Hanke, D.E.; Kraigher, H.; Osswald, W.; Rennenberg, H.; Sandermann, H.; et al. Synopsis of the CASIROZ case study: Carbon sink strength of Fagus sylvatica L. in a changing environment: Experimental risk assessment of mitigation by chronic ozone impact. Plant Biol. 2007, 9, 163-180. [CrossRef] [PubMed]

39. Matyssek, R.; Wieser, G.; Ceulemans, R.; Rennenberg, H.; Pretzsch, H.; Haberer, K.; Löw, M.; Nunn, J.J.; Werner, H.; Wipfler, P.; et al. Enhanced ozone strongly reduces carbon sink strength of adult beech (Fagus sylvatica)-Resume from the free-air fumigation study at Kranzberg Forest. Environ. Pollut. 2010, 158, 2527-2532. [CrossRef]

40. Pearcy, F.W. Sunflecks and photosynthesis in plant canopies. Annu. Rev. Plant Physiol. Plant Mol. Biol. 1990, 41, 421-453. [CrossRef]

41. Hoshika, Y.; De Marco, A.; Materassi, A.; Paoletti, E. Light intensity affects ozone-induced stomatal sluggishness in snapbean. Water Air Soil Pollut. 2016, 227, 419-425. [CrossRef]

42. Nunn, A.J.; Reiter, I.M.; Häberle, K.H.; Werner, H.; Langebartels, C.; Sandermann, H.; Heerdt, C.; Fabian, P.; Matyssek, R. "Free-Air" ozone canopy fumigation in an old-growth mixed forest: Concept and observations in beech. Phyton 2002, 42, 105-119.

43. Werner, H.; Fabian, P. Free-air fumigation of mature trees. Environ. Sci. Pollut. Res. 2002, 9, 117-121. [CrossRef]

44. Matyssek, R. Ozone sensitivity of adult forest trees. Plant Biol. 2007, 9, 163-356. [CrossRef]

45. CLRTAP. Mapping Critical Levels for Vegetation, Chapter III of manual on methodologies and criteria for modelling and mapping critical loads and levels and air pollution effects, risks and trends. UNECE Convention on Long-range Transboundary Air Pollution. 2017. Available online: http://icpvegetation.ceh.ac. uk/ (accessed on 18 October 2017).

46. Granier, A. Evaluation of transpiration in a Douglas-fir stand by means of sap flow measurements. Tree Physiol. 1987, 3, 309-320. [CrossRef] [PubMed]

47. Laisk, A.; Kull, O.; Moldau, H. Ozone concentration in leaf intercellular air spaces is close to zero. Plant Physiol. 1989, 90, 1163-1167. [CrossRef] [PubMed]

48. Wieser, G.; Matyssek, R.; Then, C.; Cieslik, S.; Paoletti, E.; Ceulemans, R. Upscaling ozone flux in forests from leaf to landscape. Ital. J. Agron. 2008, 1, 35-41. [CrossRef]

49. Draper, N.; Smith, H. Applied Regression Analysis; John Wiley and Sons Inc.: New York, NY, USA, 1981; p. 209.

50. Jung, M.; Reichstein, M.; Ciais, P.; Seneviratne, S.I.; Sheffield, J.; Goulden, M.L.; Bonan, G.; Cescatti, A.; Chen, J.; de Jeu, R.; et al. Recent Deceleration Glob. Land Evapotranspiration Due Moisture Supply Limit. Nat. 1981, 467, 951-954.

51. Pääkkonen, E.; Vahala, J.; Pohjola, M.; Holopainen, T.; Karenlampi, L. Physiological, stomatal and ultrastructural ozone responses in birch (Betula pendula Roth.) are modified by water stress. Plant Cell Environ. 1998, 21, 671-684. [CrossRef]

52. Li, L.; Manning, W.J.; Tong, L.; Wang, X.K. Chronic drought stress reduced but not protected Shantung maple (Acer truncatum Bunge.) from adverse effects of ozone $\mathrm{O}_{3}$ on growth and physiology in the suburb of Beijing. China. Environ. Pollut. 2015, 201, 34-41. [CrossRef]

53. Gao, F.; Catalayud, V.; Paoletti, E.; Hoshika, Y.; Feng, Z. Water stress mitigates the negative effects of ozone on photosynthesis and biomass in poplar plants. Environ. Pollut. 2007, 230, 268-279. [CrossRef]

54. Grulke, N.E.; Preisler, H.K.; Rose, C.; Kirsch, J.; Balduman, L. $\mathrm{O}_{3}$ uptake and drought stress effects on carbon acquisition of ponderosa pine in natural stands. New Phytol. 2002, 154, 621-631. [CrossRef]

55. Paoletti, E.; De Marco, A.; Anav, A.; Gasparini, P.; Pompei, E. Five-year volume growth of European beech does not respond to ozone pollution in Italy. Environ. Sci. Pollut. Res. 2018, 25, 8233-8239. [CrossRef]

56. Hoshika, Y.; Moura, B.B.; Paoletti, E. Ozone risk assessment in three oak species as affected by soil water availability. Environ. Sci. Pollut. Res. 2018, 25, 8125-8136. [CrossRef] 
57. Calatayud, V.; Cerveró, J.; Sanz, M.J. Foliar, physiological and growth responses of four maple species exposed to ozone. Water Air Soil Pollut. 2007, 185, 239-254. [CrossRef]

58. Nunn, A.J.; Reiter, I.M.; Haberle, K.-H.; Langebartels, C.; Bahnweg, G.; Pretzsch, H.; Sandermann, H.; Matyssek, R. Response patterns in adult forest trees to chronic ozone stress: Identification of variations and consistencies. Environ. Pollut. 2005, 136, 365-369. [CrossRef] [PubMed]

59. Kitao, M.; Löw, M.; Heerdt, C.; Grams, T.E.E.; Häberle, K.H.; Matyssek, R. Effects of chronic elevated ozone exposure on gas exchange responses of adult beech trees (Fagus sylvatica) as related to the within-canopy light gradient. Environ. Pollut. 2009, 157, 537-544. [CrossRef] [PubMed]

60. Lombardozzi, D.; Sparks, J.P.; Bonan, G.; Levis, S. Ozone exposure causes a decoupling of conductance and photosynthesis: Implications for the Ball-Berry stomatal conductance model. Oecologia 2012, 169, 651-659. [CrossRef] [PubMed]

61. Long, S.P.; Bernacchi, C.J. Gas exchange measurements, what can they tell us about the underlying limitations to photosynthesis? Proced. Sources Error. J. Exp. Bot. 2003, 54, 2393-2401. [CrossRef]

62. Niinemets, Ü.; Cescatti, A.; Rodeghiero, M.; Tosens, T. Leaf internal diffusion conductance limits photosynthesis more strongly in older leaves of Mediterranean evergreen broad-leaved species. Plantcell Environ. 2005, 28, 1552-1566. [CrossRef]

63. Matyssek, R.; Sandermann, H.; Wieser, G.; Booker, F.; Cieslik, S.; Musselman, R.; Ernst, D. The challenge of making ozone risk assessment for forest trees more mechanistic. Environ. Pollut. 2008, 156, 567-582. [CrossRef]

64. Zhang, L.; Hoshika, Y.; Carrari, E.; Badea, O.; Paoletti, E. Ozone risk assessment is affected by nutrient availability: Evidence from a simulation experiment under free air controlled exposure (FACE). Environ. Pollut. 2018, 328, 812-822.

65. Cermák, J.; Kucera, J.; Bauerle, W.L.; Phillips, N.; Hinckley, T.M. Tree water storage and its diurnal dynamics related to sap flow and changes in stem volume in old-growth Douglas-fir trees. Tree Physiol. 2007, 27, 181-198. [CrossRef]

66. Schulze, E.-D.; Cermak, J.; Matyssek, R.; Penka, M.; Zimmermann, R.; Vasicek, F.; Gries, W.; Kucera, J. Canopy transpiration and water fluxes in the xylem of the trunk of Larix and Picea trees-a comparison of xylem flow, porometer and cuvette measurements. Oecologia 1985, 66, 475-483. [CrossRef]

67. Hoshika, Y.; Omasa, K.; Paoletti, E. Whole-tree water use efficiency is decreased by ambient ozone and not affected by O3-induced stomatal sluggishness. PLoS ONE 2012, 7, e39270. [CrossRef] [PubMed]

68. Sicard, P.; Anav, A.; De Marco, A.; Paoletti, E. Projected global tropospheric ozone impacts on vegetation under different emission and climate scenarios. Atm. Chem. Phys. 2017, 17, 12177-12196. [CrossRef] 